\title{
Pengelompokan Spesies Helicotylenchus (Nematoda: Hoplolaimidae) Berdasarkan Karakter Morfologi
}

\author{
(Grouping of Species of Helicotylenchus (Nematoda: Pratylenchindae) \\ Using Morphological Characters)
}

\author{
Nie'mah Al'As"), Abdul Gafur \\ Program Studi Biologi, Fakultas Matematika dan Ilmu Pengetahuan Alam, Universitas Lambung Mangkurat \\ Jl. Ahmad Yani KM. 36, Banjarbaru, Kalimantan Selatan 70714 \\ ${ }^{*}$ Penulis Korespondensi E-mail: emah.idah@gmail.com
}

\begin{abstract}
Abstrak
Nematoda genus Helicotylenchus adalah salah satu organisme parasit yang dapat menyebabkan kerusakan pada tanaman dan dapat mengakibatkan penurunan produksi. Untuk genus ini sudah ada kompendium yang mencakup beberapa karakter diagnostik yang dapat dimanfaatkan untuk identifikasi. Akan tetapi, karena tidak ada pengelompokan spesies, maka pemanfaatan itu belum bisa terwujud. Penelitian ini dilakukan untuk melakukan pengelompokan spesies-spesies Helicotylenchus berdasarkan karakter morfologi panjang tubuh, Dorsal Oesophageal Gland Opening (DGO), panjang stilet, jumlah anulus kepala, dan jumlah anulus ekor. Pengelompokan dilakukan dengan memvisualisasi data kisaran setiap karakter menjadi hi-lo-close stock chart dengan menggunakan MS Excel. Hasil pengelompokan dengan karakter panjang tubuh terbentuk enam kelompok, DGO tujuh kelompok, panjang stilet tujuh kelompok, jumlah anulus kepala lima kelompok, dan jumlah anulus ekor lima kelompok. Pengelompokan yang paling jelas adalah berdasarkan karakter panjang tubuh. Pengelompokan ini diharapkan dapat membantu identifikasi nematoda genus Helicotylenchus sehingga kajian mengenai spesies genus ini dapat terfasilitasi.
\end{abstract}

Kata Kunci: Helicotyenchus, identifikasi, kompendium, pengelompokan.

\section{Abstract}

The genus Helicotylenchus constitutes plant parasitic nematodes that can cause damage to plants, leading to decreased crop productions. For this genus a compendium has been made that consist of diagnostic morphological characters that can be used for identification of species. However, such potential could not be realized due to lack of species groupings. In the present study groupings of species of Helicotylenchus was carried out based on morphological characters body length, Dorsal Oesophageal Gland Opening (DGO), stylet length, number of head annules, and number of tail annules. Grouping is done by visualizing the range data of each character into a hi-lo-close stock chart using MS Excel. The results were obtained for grouping with the body length characteristics of six groups, DGO of seven groups, stylet length of seven groups, number of head annulus of five groups, and number of tail annulus of five groups. Results showed that body length gave most conspicuous. This grouping is expected to assist identification of species of the genus Helicotylenchus to facilitate studies on the genus and species.

Keywords: Helicotyenchus, identification, compendium, grouping.

\section{PENDAHULUAN}

Nematoda parasit merupakan salah satu organisme yang dikenal sebagai pengganggu tanaman yang dapat menyebabkan penurunan produksi [1], khususnya pada tanaman budidaya. Salah satu nematoda yang merupakan parasit terpenting pada tanaman adalah nematoda dari genus Helicotylenchus. Genus Helicotylenchus menurut McSorley dan Parado [2] sering ditemukan pada tanaman pisang (Musa spp.) dan menyebabkan kerusakan akar, sehingga menyebabkan kerugian yang cukup besar.

Nematode genus Helicotylenchus secara umum memiliki tubuh berbentuk spiral atau cenderung melengkung, sehingga relatif mudah untuk dikenali. Saat ini, ada sekitar 230 spesies yang telah ditemukan. Firoza dan Maqbool [3] dan Uzma, dkk. [4] telah merangkum data morfometrik dan ilustrasi dan menyajikannya dalam bentuk kompendium. Data dalam bentuk tabel tersebut sudah menunjukkan adanya karakter diagnostik, sehingga dapat dimanfaatkan untuk identifikasi. Akan tetapi, hal itu belum bisa dilakukan karena dalam kompendium tersebut belum dilakukan pengelompokan spesies berdasarkan karakter-karakter yang dicakup.

Oleh karena itu, penelitian ini dilakukan dengan menganalisis dan membuat pengelompokan nematoda genus Helicotylenchus berdasarkan kompendium yang dibuat oleh Uzmi, dkk. [4]. Pengelompokan dilakukan untuk panjang tubuh, rasio a, c, c', Dorsal Oesophageal Gland Opening (DGO), letak vulva, panjang stilet, anulus kepala, dan anulus ekor.

Rasio a adalah hubungan antara panjang tubuh dan diameter tubuh dan digunakan untuk memberikan gambaran tentang kelangsingan umum suatu spesies. Rasio c menunjukkan panjang relatif dari ekor dibandingkan dengan panjang tubuh, sementara c' menyatakan hubungan panjang ekor dan lebar tubuh anal. Pada Helicotylenchus bukaan kelenjar esofagus dorsal (DGO) lebih posterior terletak di belakang dasar stylet [4].

Manfaat yang didapatkan dengan mengetahui pembagian kelompok secara spesifik untuk nematoda genus 
Helicotylenchus dari segi keilmuan, terutama bidang nematologi adalah sebagai sumber literatur ilmiah untuk pengelompokan dalam rangka identifikasi. Manfaat lain untuk keberlanjutannya dari segi pertanian diantaranya adalah untuk produksi tanaman, terutama tanaman pisang yang berhubungan dengan ketahanan pangan dan kesejahteraan petani sehingga dalam hal ini akan mudah untuk mengatasi penurunan produksi yang disebabkan oleh peningkatan dominasi nematoda genus Helicotylenchus.

\section{METODE PENELITIAN}

Pengelompokan spesies dari genus Helicotylenchus dilakukan berdasarkan kompendium yang dibuat oleh Uzma, dkk. [4]. Data yang ada dalam tabel compendium tersebut berisi kisaran setiap spesies untuk berbagai karakter dengan memuat nilai minimal dan maksimal. Data yang akan dianalisis adalah panjang tubuh, DGO (Dorsal Oesophageal Gland Opening), panjang stilet, jumlah anulus kepala, dan jumlah anulus ekor.

Langkah awal untuk pengelompokan adalah memvisualisasi data kisaran setiap karakter menjadi hi-loclose stock chart dengan menggunakan MS Excel. Dengan demikian pola pengelompokan spesies, jika ada, akan lebih mudah terlihat. Selanjutnya, batas kelompok ditentukan dengan membuat suatu garis horizontal dengan pertimbangan pada panjang nilai minimal atau maksimal dari spesies yang sudah ditentukan (Gambar 1). Aspek yang digunakan untuk batas kelompok adalah semakin sedikit spesies yang masuk pada kelompok yang sudah ditentukan, maka analisis pengelompokan akan semakin mudah dilakukan. Setelah batas kelompok ditentukan, kemudian dilakukan penentuan kode kelompok untuk tiap karakter dimulai dengan kelompok yang paling bawah. Selanjutnya, untuk masing-masing spesies dituliskan kode sesuai dengan kelompoknya.

\section{HASIL DAN PEMBAHASAN}

Analisis untuk pengelompokan spesies dari genus Helicotylenchus dilakukan pada masing-masing karakter. Salah satu karakter yang diuraikan pada bagian ini adalah karakter distribusi panjang tubuh (L) yang terdapat pada Gambar 1. Grafik yang lain dibuat pada dasarnya memiliki langkah yang sama (Gambar tidak ditunjukkan karena secara keseluruhan memiliki langkah pembuatan grafik yang sama).

Hasil pada gambar menunjukkan bahwa terdapat data spesies yang tersusun dan masuk dalam beberapa kelompok. Garis horizontal pada grafik menunjukkan batas kelompok yang sudah ditentukan, sehingga didapatkan sebanyak 6 kelompok pada Gambar 1.

Visualisasi dari grafik tersebut dapat memberikan data untuk menentukan batas kelompok yang akan ditunjukkan pada tabel untuk masing-masing karakter yang ditunjukkan pada Tabel 1. Data yang diperoleh untuk tiap masingmasing karakter kemudian digunakan untuk penentuan kode tiap spesies sesuai kelompoknya yang ditunjukkan pada Tabel 2.

Analisis data yang telah dilakukan menunjukkan bahwa karakter panjang tubuh menunjukkan pengelompokan yang paling jelas. Hal itu dikarenakan pada dasarnya kisaran untuk panjang tubuh antara spesies satu dan spesies lainnya secara garis besar memiliki karakter yang mencolok. Uzma, dkk. [4] menyatakan bahwa kisaran panjang tubuh spesies dapat membantu dalam pengenalan spesies karena kisaran ini secara konsisten lebih besar dari karakter lainnya. Hal ini didukung oleh Morand dan Poulin [5], Brown dan Maurer [6] bahwa distribusi frekuensi ukuran tubuh biasanya normal pada banyak organisme.

Pengelompokan untuk karakter DGO menunjukkan hasil yang kurang jelas dibanding karakter lainnya. Pada karakter jarak dari ujung anterior ke lubang kelenjar dorsal (DGO) merupakan salah satu karakter yang dapat digunakan untuk identikasi, tetapi secara spesifik karakter ini sulit untuk di hitung rasionya. Jaraknya dari dasar stylet serta jarak orifisi kelenjar esofagus dorsal dari dasar stylet yang dinyatakan dalam persentase panjang stylet digunakan dalam identifikasi spesies Helicotylenchus, sehingga pengamatan jarak dari dasar stilet ke DGO memerlukan pembesaran mikroskop 1000x, dan kadang-kadang tidak dapat diamati

\section{Distribusi Panjang Tubuh}

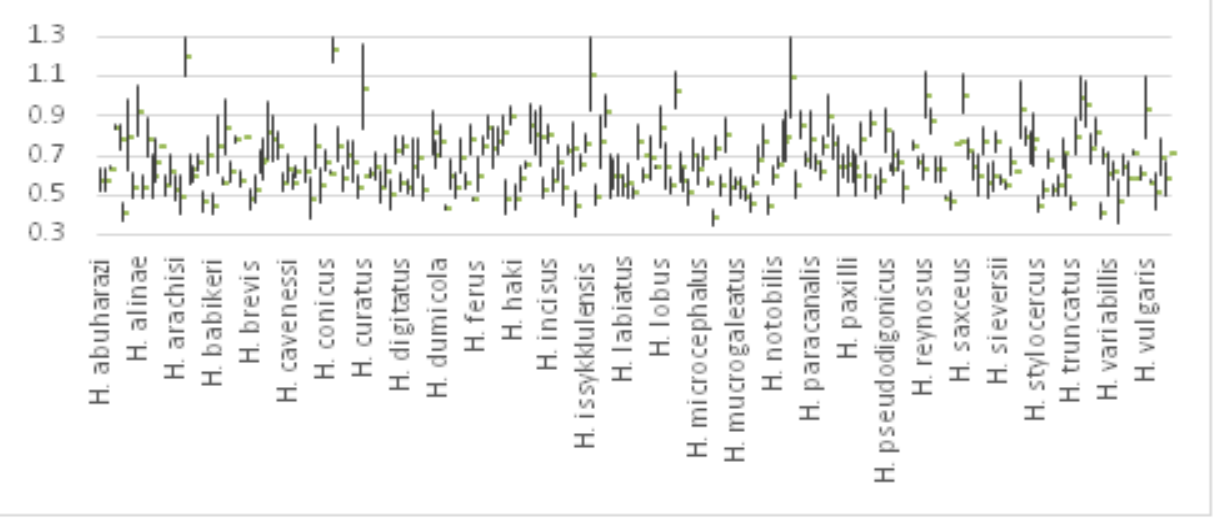

Gambar 1. Kisaran panjang tubuh (L) spesies-spesies Helicotylenchus dan pengelompokannya. 
Tabel 1. Batas kelompok untuk keseluruhan karakter

\begin{tabular}{|c|c|c|}
\hline Karakter & Kelompok & Nilai batas \\
\hline \multirow[t]{6}{*}{ Panjang tubuh (L) } & 1 & $<0,43 \mu \mathrm{m}$ \\
\hline & 2 & $0,43-0,66 \mu \mathrm{m}$ \\
\hline & 3 & $0,67-0,85 \mu \mathrm{m}$ \\
\hline & 4 & $0,86-0,98 \mu \mathrm{m}$ \\
\hline & 5 & $0,99-1,16 \mu \mathrm{m}$ \\
\hline & 6 & $>1,16 \mu \mathrm{m}$ \\
\hline \multirow[t]{7}{*}{ DGO } & 1 & $<5 \mu \mathrm{m}$ \\
\hline & 2 & $6-7 \mu \mathrm{m}$ \\
\hline & 3 & $8-9 \mu \mathrm{m}$ \\
\hline & 4 & $10-11 \mu \mathrm{m}$ \\
\hline & 5 & $12-13 \mu \mathrm{m}$ \\
\hline & 6 & $14-17 \mu \mathrm{m}$ \\
\hline & 7 & $>17 \mu \mathrm{m}$ \\
\hline \multirow[t]{7}{*}{ Panjang stilet } & 1 & $<19 \mu \mathrm{m}$ \\
\hline & 2 & $19-22,5 \mu \mathrm{m}$ \\
\hline & 3 & $22,6-27,5 \mu \mathrm{m}$ \\
\hline & 4 & $27,6-32 \mu \mathrm{m}$ \\
\hline & 5 & $33-35 \mu \mathrm{m}$ \\
\hline & 6 & $36-42 \mu \mathrm{m}$ \\
\hline & 7 & $>42 \mu \mathrm{m}$ \\
\hline \multirow[t]{5}{*}{ Jumlah anulus kepala } & 1 & $2-3 \mu \mathrm{m}$ \\
\hline & 2 & $4-5 \mu \mathrm{m}$ \\
\hline & 3 & $6-7 \mu \mathrm{m}$ \\
\hline & 4 & $8-10 \mu \mathrm{m}$ \\
\hline & 5 & $>11 \mu \mathrm{m}$ \\
\hline \multirow[t]{5}{*}{ Jumlah anulus ekor } & 1 & $<6 \mu \mathrm{m}$ \\
\hline & 2 & $6-11 \mu \mathrm{m}$ \\
\hline & 3 & $12-16 \mu \mathrm{m}$ \\
\hline & 4 & $17-24 \mu \mathrm{m}$ \\
\hline & 5 & $>24 \mu \mathrm{m}$ \\
\hline
\end{tabular}

Tabel 2. Pengelompokan spesies-spesies Helicotylenchus untuk beberapa karakter morfologis

\begin{tabular}{|c|c|c|c|c|c|}
\hline Spesies & $\mathrm{L}$ & DGO & Panjang stilet & Anulus kepala & Anulus ekor \\
\hline H. abuharazi & 2 & $4,5,6$ & 2,3 & 2 & 1,2 \\
\hline H. abunaamai & 2 & - & 2 & 2 & 2 \\
\hline H. acunae & 2,3 & - & 4 & 2 & 2 \\
\hline H. acutucaudatus & 3,4 & - & 5 & 2 & 2 \\
\hline H. acutus & 2,3 & 2,3 & 4 & 2 & 1,2 \\
\hline H. affinis & 1,2 & 3 & 3 & 2 & - \\
\hline H. africanus & $2,3,4$ & - & 4 & 2 & 2,3 \\
\hline H. agricola & 2 & 3 & 2,3 & 2 & 2 \\
\hline H. alinae & $2,3,4$ & $4,5,6$ & 4,5 & 2 & 3 \\
\hline H. amabilis & 2 & - & 3 & 2 & 2,3 \\
\hline H. amplius & 3,4 & 7 & 4 & - & 2,3 \\
\hline
\end{tabular}




\begin{tabular}{|c|c|c|c|c|c|}
\hline Spesies & $\mathrm{L}$ & DGO & Panjang stilet & Anulus kepala & Anulus ekor \\
\hline H. angularus & 2,3 & 4 & 3 & 1,2 & 2,3 \\
\hline H. anhelicus & 2,3 & - & 4,5 & 3 & 2 \\
\hline H. annobonensis & 3 & - & - & - & - \\
\hline H. apiculus & 2 & 4 & 3 & 3 & - \\
\hline H. aquili & 2,3 & - & 3 & 2 & 2 \\
\hline H. arachisi & 2 & 3,4 & 2,3 & 2 & - \\
\hline H. areolatus & 2 & - & 3 & 2 & 2 \\
\hline H. arliani & 5,6 & 4,5 & 6 & 3 & 4 \\
\hline H. assamensis & 2,3 & 4,5 & 3,4 & 2 & 3,4 \\
\hline H. astriatus & 2,3 & 2 & 2 & - & 1 \\
\hline H. atlanticus & 2,3 & - & 3 & 2 & 2 \\
\hline H. attenuatus & 2 & 2,3 & 3 & 2 & 2,3 \\
\hline H. australis & 2,3 & - & 2,3 & - & $2,3,4$ \\
\hline H. babikeri & 2 & 2 & 1 & 2 & 2,3 \\
\hline H. bajoriensis & $2,3,4$ & 5,6 & 2,3 & 2 & - \\
\hline H. bambasae & 2 & 5 & 2,3 & 3 & 2 \\
\hline H. belli & 3,4 & - & 4 & - & 4 \\
\hline H. belurensis & 2,3 & 4 & 3 & 3 & 2,3 \\
\hline H. bifurcatus & 3 & - & 4 & 2 & 2 \\
\hline H. bihari & 2 & 3,4 & 2 & 3 & 1,2 \\
\hline H. brassicae & 3 & - & 4 & - & - \\
\hline H. brevis & 2 & - & 3,4 & 2 & - \\
\hline H. brevicaudatus & 2 & 6 & 2,3 & 2 & 1,2 \\
\hline H. caipora & 2,3 & - & 3 & 2 & 1,2 \\
\hline H. californicus & 2,3 & - & 3 & 2 & 2 \\
\hline H. canadensis & 3,4 & 2,3 & 4 & 2 & 2,3 \\
\hline H. canalis & 3,4 & - & 5 & 3 & 1 \\
\hline H. caroliniensis & 3 & - & 3,4 & 2 & 3 \\
\hline H. caudatus & 2 & - & 3,4 & 2 & 2,3 \\
\hline H. cavenessi & 2,3 & - & 3 & 2 & 3 \\
\hline H. cedreus & 2 & - & 3 & - & - \\
\hline
\end{tabular}




\begin{tabular}{|c|c|c|c|c|c|}
\hline Spesies & $\mathrm{L}$ & DGO & Panjang stilet & Anulus kepala & Anulus ekor \\
\hline H. certus & 2,3 & 3,4 & 3 & 2 & 2 \\
\hline H. cheni & - & - & - & - & - \\
\hline H. clarkei & 2,3 & - & 3 & - & 3 \\
\hline H. coffae & 1,2 & - & 3 & 2 & 2,3 \\
\hline H. concavus & $2,3,4$ & - & 4,5 & - & $1,2,3$ \\
\hline H. conicephalus & 2 & - & 2,3 & -- & 2 \\
\hline H. conicus & 2,3 & 3,4 & 3 & & 2,3 \\
\hline H. constrictus & 2 & $3,4,5$ & 2 & - & 2 \\
\hline H. coomansi & 6 & - & 6 & 2 & 2,3 \\
\hline H. cornurus & 3,4 & $3,4,5$ & 3 & 2 & 1,2 \\
\hline H. craigi & 2,3 & - & 2,3 & 2 & 2 \\
\hline H. crassatus & 2,3 & - & 3,4 & 2 & 1,2 \\
\hline H. crenacauda & 2,3 & - & 3,4 & 2 & 2 \\
\hline H. crotinii & 2 & 6 & 2,3 & 2 & 1,2 \\
\hline H. curatus & $3,4,5,6$ & $1,2,3$ & 7 & 3 & 3,4 \\
\hline H. curvatus & 2 & 3,4 & 2 & 2 & - \\
\hline H. curvicaudatus & 2 & - & 4 & 2 & 3 \\
\hline H. cuspicaudatus & 2,3 & 4,5 & 3,4 & 2 & 4 \\
\hline H. delanus & 2 & 2,3 & 3,4 & 3 & 1,2 \\
\hline H. delhiensis & 2,3 & 3 & 2 & 1 & 2 \\
\hline H. densibullatus & 2 & - & 2,3 & 2 & 2 \\
\hline H. depressus & 3 & - & 3 & 2 & 2,3 \\
\hline H. digitatus & 2 & 3 & 2 & 2 & 3,4 \\
\hline H. digitformis & 3 & - & 4 & 3 & 3,4 \\
\hline H. dignus & 2 & - & 3 & 1,2 & - \\
\hline H. digonicus & 2,3 & - & 3,4 & 2 & 1,2 \\
\hline H. dihystera & 2,3 & - & 3,4 & 2 & $1,2,3$ \\
\hline H. discocephalus & 2 & 4,5 & 2,3 & 2 & 1,2 \\
\hline H. distinctus & - & - & - & - & - \\
\hline$H$ & & - & & & \\
\hline dolichodoryphous & 3,4 & & 5,6 & 3 & 1 \\
\hline H. dumicola & 2,3 & $4,5,6$ & 6 & 2 & 2,3 \\
\hline
\end{tabular}




\begin{tabular}{|c|c|c|c|c|c|}
\hline Spesies & $\mathrm{L}$ & DGO & Panjang stilet & Anulus kepala & Anulus ekor \\
\hline H. egyptiensis & 3 & 4,5 & 3,4 & 2,3 & 2,3 \\
\hline H. elegans & 2 & 4,5 & 2,3 & 3 & - \\
\hline H. eletropicus & 2,3 & 3 & 3 & 2 & 3 \\
\hline H. erythrinae & 2 & - & 3 & 2 & $1,2,3$ \\
\hline H. exallus & 2,3 & - & 3,4 & 2 & 3 \\
\hline H. falcatus & 2 & 3,4 & 2 & - & 2 \\
\hline H. fericulus & 3,4 & 6 & 4 & 2 & 3,4 \\
\hline H. ferus & 2 & 4,5 & 2,3 & - & - \\
\hline H. gerti & 2,3 & $3,4,5$ & 2,3 & 2 & 1,2 \\
\hline H. girus & 3 & - & 3 & - & - \\
\hline H. goldeni & 3,4 & 2,3 & 4,5 & 3 & 3 \\
\hline H. goodi & $2,3,4$ & - & 3 & - & 2 \\
\hline H. graminophilus & 3,4 & - & 3,4 & - & 2,3 \\
\hline H. gratus & 3,4 & - & 3 & - & 3,4 \\
\hline H. gulabi & 2 & 4 & 2,3 & - & 2 \\
\hline H. haki & 4 & - & 4 & 3 & 4 \\
\hline H. handooi & 2 & - & 2 & 2 & 3 \\
\hline H. hazratbalensis & 2,3 & - & 2,3 & 2 & 2 \\
\hline H. holguinensis & 2,3 & 6 & 3 & 2 & 2 \\
\hline H. hoplocaudus & 3,4 & - & 4 & - & - \\
\hline H. hydrophilus & 3,4 & - & 4 & 2 & - \\
\hline H. impar & 3,4 & 4 & 3,4 & 2 & 3,4 \\
\hline H. imperialis & $2,3,4$ & 4 & 3,4 & 2 & 2,3 \\
\hline H. incisus & 2 & - & 3 & - & - \\
\hline H. indentatus & 3,4 & - & 3,4 & 2 & 1,2 \\
\hline H. indenticaudatus & 2,3 & 4,5 & 2,3 & 3 & 3,4 \\
\hline H. indicus & 2,3 & 3 & - & 2 & 2 \\
\hline H. inifatus & 2 & - & 4 & 2 & 2 \\
\hline H. insignis & 3 & 6 & 3 & 2 & 2 \\
\hline H. intermedius & $2,3,4$ & 3 & 3 & 2 & 1,2 \\
\hline H. interrogativus & 2 & 4 & 4 & 2 & 3,4 \\
\hline
\end{tabular}




\begin{tabular}{|c|c|c|c|c|c|}
\hline Spesies & $\mathrm{L}$ & DGO & Panjang stilet & Anulus kepala & Anulus ekor \\
\hline H. issykklulensis & 2,3 & - & 3 & 3 & - \\
\hline H. jammиеnsis & 3 & - & 4,5 & 3 & 3 \\
\hline H. jasminii & $4,5,6$ & 4 & 2,3 & 2 & 2 \\
\hline H. jojutlensis & 2 & - & 4 & 2 & 2 \\
\hline H. kashmirensis & $2,3,4$ & - & 5 & 4 & 3,4 \\
\hline H. kermarreci & 4 & 2,3 & 2 & 2 & 2,3 \\
\hline H. kherai & 2,3 & - & 3 & 2 & 2,3 \\
\hline H. krugeri & 2,3 & - & 3,4 & - & $2,3,4$ \\
\hline H. labiatus & 2,3 & 4 & 3 & 2 & - \\
\hline H. labiodiscinus & 2 & - & 3 & - & 3 \\
\hline H. laevicaudatus & 2,3 & 4 & 3 & - & 2 \\
\hline H. leiocephalus & 2 & - & 3,4 & - & 2 \\
\hline H. lemoni & 3,4 & 3,4 & 2 & 2 & 2,3 \\
\hline H. limarius & 2 & - & 4 & 2 & 2 \\
\hline H. limatus & 3 & 7 & 4,5 & 2 & 2,3 \\
\hline H. lissocaudatus & 2,3 & - & 4 & 2 & 2 \\
\hline H. lobus & 2,3 & - & 4 & 3 & 2 \\
\hline H. longicaudatus & 3,4 & - & 3,4 & - & 2 \\
\hline H. macronatus & 2,3 & 3,4 & 2 & 2 & - \\
\hline H. macrostylus & 2 & 5 & 7 & 4 & 2 \\
\hline H. magnicephalus & 4,5 & 4,5 & 2,3 & - & 2 \\
\hline H. marethae & 2,3 & 3 & 3 & - & 3,4 \\
\hline H. martini & 2,3 & - & 2,3 & - & 2 \\
\hline H. meloni & 2 & 5 & 3 & 2 & 2 \\
\hline H. microcephalus & 2,3 & - & 3 & - & 2 \\
\hline H. microdorus & 2,3 & 3 & 1,2 & 2 & - \\
\hline H. microtylus & 2,3 & 3,4 & 3 & 2 & 1 \\
\hline H. minutus & 2 & 4 & 2 & 2 & 2,3 \\
\hline H. minzi & 1,2 & - & 3,4 & 3 & 2 \\
\hline H. monstruosus & 3 & - & 3 & 3 & 3,4 \\
\hline H. montanus & 2 & - & 4 & 2 & - \\
\hline
\end{tabular}




\begin{tabular}{|c|c|c|c|c|c|}
\hline Spesies & $\mathrm{L}$ & DGO & Panjang stilet & Anulus kepala & Anulus ekor \\
\hline H. morasii & 3,4 & 3 & 1,2 & 3 & 2,3 \\
\hline H. mucrogaleatus & 2 & - & 3 & 2 & 1,2 \\
\hline H. mucronatus & 2 & 5 & 2,3 & 2 & - \\
\hline H. multicinctus & 2 & - & 2,3 & 2 & $1,2,3$ \\
\hline H. mundus & 2 & 3,4 & 2 & 2 & 2,3 \\
\hline H. neoformis & 2 & 4 & 2,3 & 2 & 2 \\
\hline H. neopaxilli & 2,3 & - & 3 & 2 & 2,3 \\
\hline H. nigeriensis & 3,4 & - & 4,5 & 3 & 1 \\
\hline H. nitens & 2 & 3 & 2 & 1 & 2,3 \\
\hline H. notobilis & 2,3 & 5 & 2,3 & 2 & - \\
\hline H. obliquus & 2,3 & - & 2,3 & 2 & 2,3 \\
\hline H. obtusicaudatus & 3,4 & - & 3 & - & - \\
\hline H. oleae & 3,4 & - & 4 & 2 & 4 \\
\hline H. orthosomaticus & $4,5,6$ & - & 5 & & 3,4 \\
\hline H. oryzae & 2 & - & 3 & 3 & 2 \\
\hline H. oscephalus & 3,4 & 2,3 & 3,4 & 3,4 & 3,4 \\
\hline H. parabelli & 2,3 & - & 3,4 & - & 4 \\
\hline H. paracanalis & $2,3,4$ & - & 5,6 & 3 & 1,2 \\
\hline H. paraconcavus & 2,3 & - & 3,4 & - & 3 \\
\hline H. paracrenacauda & 2,3 & 3,4 & 3,4 & 2 & 1,2 \\
\hline $\begin{array}{l}\text { H. } \\
\text { paradihysteroides }\end{array}$ & 3 & - & 3 & 2 & 2,3 \\
\hline H. paragirus & $3,4,5$ & - & 3 & 2 & 1,2 \\
\hline H. paraplatyurus & 3,4 & - & 3 & 2 & 3,4 \\
\hline H. parapteracercus & 2,3 & 2 & 3,4 & 3 & 2,3 \\
\hline H. pasohi & 2,3 & - & 3,4 & 3 & 1,2 \\
\hline H. paxilli & 2,3 & 3 & 4 & 3 & 2,3 \\
\hline H. persiaensis & 2,3 & 4 & 2,3 & 2 & 1,2 \\
\hline H. persici & 2,3 & & 2 & 2 & - \\
\hline H. pisi & 3,4 & 6 & 3,4 & 2 & 3 \\
\hline H. planquettei & 2,3 & 4,5 & 4 & 2 & 1,2 \\
\hline H. platyurus & 3,4 & & 4 & 2 & $2,3,4$ \\
\hline
\end{tabular}




\begin{tabular}{|c|c|c|c|c|c|}
\hline Spesies & $\mathrm{L}$ & DGO & Panjang stilet & Anulus kepala & Anulus ekor \\
\hline H. plumariae & 2 & 3,4 & 2,3 & 2 & 2 \\
\hline H. pricei & 2 & 3,4 & 4 & 2 & 2,3 \\
\hline H. pseudodigonicus & 3,4 & - & 3,4 & 3 & 2,3 \\
\hline H. pseudopaxilli & 2,3 & - & 3 & 2 & 2 \\
\hline H. pseudorobustus & $2,3,4$ & - & 3,4 & 2 & 2,3 \\
\hline H. pteracercus & 2,3 & - & 3 & 3 & 2,3 \\
\hline H. rajcolagri & 2 & 6 & 2,3 & 2 & 2 \\
\hline H. raskii & - & - & - & - & - \\
\hline H. retusus & 2 & 5 & 3 & 2 & 2 \\
\hline H. reversus & 2,3 & - & 3,4 & 2 & 2,3 \\
\hline H. reynosus & 2,3 & - & 3 & 2 & 2 \\
\hline H. rohtangus & 4,5 & 5,6 & 5 & 3 & 4,5 \\
\hline H. ryzhikovi & 3,4 & - & 5 & - & - \\
\hline H. sacchari & 2,3 & - & 2,3 & 3 & 2 \\
\hline H. saccharumi & 2,3 & - & 2,3 & 2 & 2 \\
\hline H. sagitovi & 2 & 6 & 3 & 2 & 2,3 \\
\hline H. samorensis & 2 & 4 & 2 & 2 & 2 \\
\hline H. sandersae & 3 & - & 2 & 3 & 2 \\
\hline H. saxceus & 3 & 6 & 5 & 3 & 3 \\
\hline H. scoticus & 4,5 & - & 4 & 2 & 123 \\
\hline H. serenus & 3 & 3 & 4 & 2 & 3 \\
\hline H. seshadrii & 2,3 & - & 2,3 & 2 & 34 \\
\hline H. shakili & 2,3 & - & 3 & 2 & 34 \\
\hline H. sharafati & 3,4 & $3,4,5$ & 3 & 1 & 234 \\
\hline H. sheri & 2,3 & $3,4,5$ & 2,3 & 2 & \\
\hline H. shervarayensis & 2,3 & 5,6 & 3,4 & 2 & 2 \\
\hline H. sieversii & 3,4 & - & 5 & 3 & 2 \\
\hline H. silvaticus & 2 & 2 & 2 & - & 234 \\
\hline H. similis & 2 & - & 2 & 2 & 12 \\
\hline H. solani & 2,3 & - & 3,4 & 3 & 34 \\
\hline H. sparsus & 2 & - & 3 & 2 & 2 \\
\hline
\end{tabular}




\begin{tabular}{|c|c|c|c|c|c|}
\hline Spesies & $\mathrm{L}$ & DGO & Panjang stilet & Anulus kepala & Anulus ekor \\
\hline H. spitsbergensis & $3,4,5$ & 3 & 3,4 & 2 & 3 \\
\hline H. steineri & 3 & - & 2,3 & 2 & 4 \\
\hline H. striatus & 2,3 & $3,4,5$ & 3 & 2 & 23 \\
\hline H. stylocercus & $2,3,4$ & 5 & 3 & 2 & 345 \\
\hline H. subterminalis & 1,2 & 3 & 3 & 2 & 2 \\
\hline H. subtropicalis & 2 & - & 2,3 & 2 & 2 \\
\hline H. tangericus & 2,3 & - & 3,4 & 3 & 2 \\
\hline H. teres & 2 & 4 & 2 & 2 & 2 \\
\hline H. thornei & 2 & 4,5 & 3 & - & - \\
\hline$H$ & & & & & \\
\hline trapezoidicaudatus & 2,3 & 4 & 3,4 & 2 & 2 \\
\hline H. tropicus & 2,3 & 4 & 3 & 2 & - \\
\hline H. truncatus & 1,2 & 3 & 2 & 2 & - \\
\hline H. tumidicaudatus & 3,4 & 5 & 3,4 & - & 3 \\
\hline H. tunisiensis & 4,5 & 3 & 5 & 2 & - \\
\hline H. unicum & $3,4,5$ & - & 4 & 2 & 2 \\
\hline H. urobelus & 2,3 & 3,4 & 3,4 & 2 & 2,3 \\
\hline H. ussuriensis & 3,4 & 4 & 4 & 3 & 3,4 \\
\hline H. valdeclarus & 1,2 & - & 2 & - & 2,3 \\
\hline H. valecus & 2,3 & - & 4,5 & 2 & 2,3 \\
\hline H. variabillis & 2,3 & 6 & 3 & - & 3 \\
\hline H. varicaudatus & 2 & 3,4 & 4,5 & 3 & 1,2 \\
\hline H. variocaudatus & 1,2 & 3,4 & 3,4 & 2 & 2,3 \\
\hline H. ventroprojectus & 2,3 & - & 3,4 & - & 3 \\
\hline H. verecundus & 2 & 3,4 & 2 & 3 & 2,3 \\
\hline H. verrucosus & 3 & - & 5 & 2 & 1 \\
\hline H. vietnamiensis & 2 & - & 3 & 2 & - \\
\hline H. vindex & 2 & 5,6 & 2 & 2 & 4 \\
\hline H. vulgaris & $3,4,5$ & 4,5 & 4,5 & 3 & 1,2 \\
\hline H. wajihi & 2 & - & 3 & 3 & 1,2 \\
\hline H. whiteheadi & 1,2 & 1 & 2 & 2 & - \\
\hline H. willmottae & 2,3 & 6 & 3,4 & 3 & 3,4 \\
\hline
\end{tabular}




\begin{tabular}{lccccc}
\hline \multicolumn{1}{c}{ Spesies } & L & DGO & Panjang stilet & Anulus kepala & Anulus ekor \\
\hline H. wilmae & 2 & 4,5 & 3,4 & 5 & $2,3,4$ \\
H. zeidani & 2,3 & $1,2,3,4,5$ & 2 & - & 2,3
\end{tabular}

Keterangan: Angka pada kolom (karakter) menunjukkan kode kelompok untuk karakter; (-): menunjukkan spesies tersebut tidak terdata masuk dalam kelompok karena nilai minimum dan maksimumnya tidak diketahui.

Ciri diagnostik yang didapatkan pada beberapa karakter dapat dijadikan acuan untuk pengelompokan. Nilai minimum dan maksimum dijadikan sebagai acuan kisaran nilai spesies untuk karakter yang bersangkutan. Hal ini didukung dengan hasil pengelompokan berdasarkan karakter morfologis yang digunakan. Spesies yang kisarannya mengenai batas untuk suatu kelompok akan dimasukkan ke dalam kelompok tersebut.

Nilai maksimum dan minum menunjukkan bagaimana beberapa spesies dapat dimasukkan dalam pengelompokan nematoda Helicotylenchus. Dalam grafik hasil pengelompokan menunjukkan bahwa semakin besar nilai maksimum dan semakin kecil nilai minimum karakter, maka semakin banyak pula spesies yang akan masuk dalam batas kelompok awal dan akhir, sehingga akan memudahkan pengelompokan spesies. Pada semua karakter juga terdapat beberapa spesies yang masuk dalam beberapa kelompok. Hal ini disebabkan karena nilai panjang minimum dan maksimumnya melebihi dari batas kelompok yang sudah ditentukan. Spesies yang masuk dalam beberapa kelompok menunjukkan bahwa spesies tersebut memiliki kemungkinan masuk pada kelompok yang tidak jelas. Hasil pengelompokan yang sudah dilakukan dapat digunakan sebagai karakter-karakter tambahan untuk dikombinasi dengan karakter yang lain dalam upaya identifikasi spesies nematoda dari genus Helicotylenchus.

Kriteria untuk mengalokasikan individu ke dalam pengelompokan sering akan sulit dilakukan jika spesies dalam kelompok yang sama diketahui bervariasi dalam sumber makanannya dan respons terhadap gangguan [7]. Untuk menilai ketahanan tanah, identifikasi tingkat spesies harus dicapai, kemudian pengelompokan kelompok perlu dipertimbangkan dalam rangka identifikasi secara lanjut [8] [9].

Pengelompokan spesies dapat digunakan untuk identifikasi lanjutan yang juga bertujuan untuk strategi pengendalian [10]. Oro, dkk. [11] dan Sa'diyah [12], menyatakan identifikasi morfologi nematoda genus Helicotylenchus dapat dilakukan dengan metode morfometrik dengan analisis pengukuran stilet, panjang vulva, anus, dan kutikula serta beberapa karakter morfologi lainnya. Hasil yang akan didapatkan pada identifikasi dengan karakter morfologi mampu memberikan identifikasi lanjutan pada tahap pengelompokan. Oleh sebab itu, dengan adanya hasil penelitian ini diharapkan dapat menjadi acuan dan sumber ilmiah tambahan untuk pengelompokan spesies-spesies nematoda dari genus Helicotylenchus sebagai salah satu upaya studi pengendalian, dalam rangka meningkatkan produksi tanaman.

\section{KESIMPULAN}

Spesies-spesies nematoda dari genus Helicotylenchus dapat dikelompokkan berdasarkan morfologi panjang tubuh, Dorsal Oesophageal Gland Opening (DGO), panjang stilet, jumlah anulus kepala, dan jumlah anulus ekor. Pengelompokan yang paling jelas adalah berdasarkan panjang tubuh. Pengelompokan yang dilakukan dengan karakter morfologi dapat memberikan manfaat untuk membantu identifikasi spesies Helicotylenchus. Pengelompokan ini akan membantu dalam identifikasi morfologis spesies. Identifikasi yang akurat merupakan salah satu syarat utama untuk upaya mengatasi serangan nematoda Helicotylenchus dan penurunan produksi yang disebabkannya. Identifikasi nematoda parasit tanaman perlu dilakukan untuk dapat mengambil langkah dan strategi penanganan dampaknya.

\section{DAFTAR PUSTAKA}

[1] Wallace, H. R. 1973. Nematode Ecology and Plant Diseases. Edward Arnold, London.

[2] McSorley R., \& Parrado, J. L. (1980). The Spiral Nematode Helicotylenchus Multicinctus On Bananas In Florida And Its Control. Proceedings of the Florida State Horticultural Society 96: 201-207.

[3] Firoza, K. \& Maqbool, M. A. (1994). Descriptions of Helicotylenchus meloni and H. striatus sp. (Nematoda: Haploimidae) from Pakistan. Pakistan Journal of Nematology. 12: 109-116.

[4] Uzma, K. N., K. Firoza, \& F. Shahina. (2015). Review of the Genus Helicotylenchus Steiner, 1945 (Nematoda: Hoploaimidae) with Updated Diagnostik Compendium. Pakistan Journal of Nematology. 33: 115-160.

[5] Morand, S., \& R. Poulin. (2002). Body Size-density Relationships and Species Diversity in Parasitic Nematodes: Patterns and Likely Process. Evolutionary Ecology Research. 4: 951-961.

[6] Brown, J. H., \& B. A. Maurer. (1988). Macroecology: The Division of Food and Space Species On Continents. Science. 241: 1145-1150.

[7] Yeast, G. W., T. Bongers, R. De Goede, D. Freckman, \& S. Georgieva. (1993). Feeding Habits in Soil Nematode Famillies and Genera- An Outline For Soil Ecologiest. J. Nematol. 25: 315-331.

[8] Yeast, G. W. (2003). Nematodes As Soil Indicators: Functional and Biodiversity Aspects. Biol Fert Soil. 37: 199-210.

[9] Ahmed, M., M. Sapp, T. Prior, G. Karssen, \& M. Back. (2015). Nematode Taxonomy: From 
Morphology to Metabarcoding. SOIL Discuss. 2: 1175-1220.

[10] Whitehead, A. G. (1998). Plant Nematode Control. CAB International. Cambridge University Press, UK.

[11] Oro, V., Z. Ivanovic, B. Nikolic, L. Barszi, M. Radivojevic, \& B. Jovcic. (2010). Morphological and Molecular Identification of Potato Cyst Nematode Populations in Serbia. Arch Biol Sci. 62: 747-754.
[12] Sa'diyah, H. (2016). Identifikasi Nematoda Parasit Tanaman pada Tembakau (Nicotiana tabacum L.,) Berbasis Molekuler di Daerah Lumajang, Probolinggo, dan Se-karesidenan Besuki. Skripsi. Agroteknologi, Fakultas Pertanian, Univeristas Jember. 